\title{
Characterization of Nuclear 3,5,3'-Triiodothyronine Receptors in the Developing Rat Lung: Effects of Hypo- and Hyperthyroidism
}

\author{
J. RUEL, P. COULOMBE ${ }^{(38)}$, AND J. H. DUSSAULT \\ Laboratoires de Recherches en Endocrinologie et Métabolisme, Le Centre Hospitalier de l'Université Laval, \\ 2705 Boul. Laurier, Ste-Foy, Qué., Canada GIV 4G2
}

\section{Summary}

In this study, we measured the changes in binding characteristics of $T_{3}$ to its nuclear receptor in lungs of rats from 2 days of age to adulthood. In all ages studied, we found a single class of binding sites with a mean $\mathrm{Ka}$ of $1.16 \pm 0.05 \times 10^{10} \mathrm{M}^{-1}$. The specificity of the nuclear receptor, as judged by the relative affinities of thyroid hormone analogs, is in general agreement with data previously reported for lung and other organs. A significant decrease in the maximum binding capacity of the lung $T_{3}$ receptor occurs between 30 and 40 days of age: 0 to 30 days, $0.208 \pm 0.005$ pmole $T_{3} / \mathrm{mg}$ protein; 40 days to adulthood, $0.111 \pm 0.007$ pmole $T_{3} / \mathrm{mg}$ protein. Our experiments showed that this reduction is not due to differential recovery of nuclei or efficiency of extraction at various ages. The relative saturation of the nuclear receptor increases from $26 \%$ at 2 days of age to $48 \%$ in the adult animal. Thyroid status has no significant effect on the nuclear $T_{3}$ binding capacity of developing rat lung up to 11 days of age. However, hyperthyroidism substantially increased the binding capacity in lungs of adult animals $\left(0.157 \pm 0.009\right.$ versus $0.108 \pm 0.006$ pmole $T_{3} / \mathrm{mg}$ protein), without a corresponding reduction in hypothyroidism $(0.116 \pm 0.007$ pmole $\mathrm{T}_{3} / \mathrm{mg}$ protein). These findings suggest that thyroid hormones play a yet unspecified important role in lung physiology during the first month of life in the rat.

\section{Speculation}

The level of nuclear $T_{3}$ receptor remains relatively high for the first month of life in the rat lung and the saturation of the binding sites increases during this period. This would support the hypothesis that thyroid hormones act directly to influence aspects of pulmonary maturation, possibly alveolarization, during that period.

Thyroid hormones are important regulators of differentiation and development in many tissues (17). During the last few years, some studies have suggested that thyroid hormones influence the maturation of the pulmonary surfactant system. This complex material, composed mainly of phospholipids, lines the alveoli. Its presence appears to reduce the incidence and severity of the respiratory distress syndrome (15). Administration of thyroxine or analogs accelerates the maturation of the pulmonary surfactant system in lungs of rabbit (36), rat (20), and human (25) fetuses whereas it is retarded by thyroidectomy in ovine fetal lung (14). Pulmonary surfactant maturation occurs before birth in all these species. In the rat, the fetal pituitary-thyroid axis functions independently of the maternal system $(11,12)$ and the maturation of the thyroid system occurs primarily during the first month after birth (13). Thus, the role of endogenous thyroid hormones in pulmonary surfactant maturation is not clearly established. Al- though functional, rat lungs are still not mature at birth since they contain no true alveoli. Important changes in morphology, morphometry, and cell population occur during the first 3 postnatal weeks in the rat $(4,5,21)$. These postnatal changes constitute events that could be affected by thyroid hormones. In this regard, thyroxine treatment has been reported to accelerate the development of drug permeability characteristics to the point of maturity in the neonatal rat lung (19).

Thyroid hormone action is generally thought to be initiated by the binding of $T_{3}$ to a class of nonhistone nucleoprotein in target organs, followed by the activation of specific genes $(2,27)$. The presence of such receptors has recently been described in lungs of both fetal and adult rodents $(23,26)$, suggesting that thyroid hormones might act directly on the lung.

In order to establish an eventual correlation between thyroid hormones and lung maturation, one would need to know more about the characteristics of nuclear receptors throughout development. In this study, we measured the changes in binding characteristics of $T_{3}$ to its nuclear receptor in lungs of rats from 2 days of age to adulthood. We also examined the effects of hypoand hyperthyroidism on the characteristics of $T_{3}$ binding to this nuclear receptor. The results of these experiments are presented in this communication.

\section{MATERIALS AND METHODS}

MATERIALS

High specific activity $\left[{ }^{125} \mathrm{I}\right]-\mathrm{T}_{3}(900-1300 \mu \mathrm{Ci} / \mu \mathrm{g})$ was purchased from New England Nuclear Co., Boston, MA. Nonlabeled L-T $\mathrm{D}-\mathrm{T}_{3}, \mathrm{~L}-\mathrm{T}_{4} \mathrm{D}-\mathrm{T}_{4}$, and TRIAC (triiodothyroacetic acid) were obtained from Sigma Chemicals Co., St. Louis, MO while L-T (3, $3^{\prime}$-diiodo-L-thyronine) and $\mathrm{rT}_{3}$ were from Hennings Co., Berlin, Germany. DIMIT (3,5-dimethyl-3'-isopropyl-L-thyronine) was a gift from Dr. E. C. Jorgensen of the University of California, San Francisco.

\section{TREATMENT OF ANIMALS}

Sprague-Dawley female rats and their pups were obtained from a commercial supplier (Canadian Breeding Farms, St-Constant, Laprairie, Canada). The mothers and their pups were housed in individual cages in a sound-attenuated, temperature and lightcontrolled room ( $14 \mathrm{hr}$ light, $10 \mathrm{hr}$ darkness) and allowed free access to rat laboratory food and water. Both male and female animals were used throughout the experiments. Adult animals were at least 110 days of age.

Hypothyroidism was induced in adult rats by feeding them a solution of 6-n-propyl-thiouracil (PTU) $(0.05 \%)$ in the drinking water for a period of $6 \mathrm{wk}$. Neonatal hypothyroidism was induced 
by feeding pregnant rats the same PTU solution from the 14th day of gestation until parturition. After birth, the PTU solution was replaced by tap water, and $100 \mu \mathrm{g}$ of PTU in $1 \%$ carboxymethyl-cellulose was injected sc daily into the pups.

Hyperthyroidism was induced in adult rats by daily ip administration of $\mathrm{T}_{4}(40 \mu \mathrm{g} / 100 \mathrm{~g} \mathrm{bw})$ for a period of 6 days. Neonatal hyperthyroidism was induced by sc injection of $T_{4}(40 \mu \mathrm{g} / 100 \mathrm{~g}$ body weight) from birth to the days as indicated in the figures and tables.

\section{PREPARATION OF THE NUCLEAR EXTRACT}

Pups were decapitated at different ages and lungs were rapidly removed and chilled on ice. In one experiment, time-dated pregnant rats were decapitated on the 21 st day of gestation and the fetuses obtained by uterotomy. Four pools of tissue were used in each age group except in 30- and 50-day-old groups $(n=5)$ and in fetuses $(n=2)$. When examining the effects of hypo- and hyperthyroidism, determinations were performed simultaneously in control and treated groups of the same age. All subsequent operations were done at $0^{\circ} \mathrm{C}$. Tissue $(1$ to $2 \mathrm{~g})$ was minced, homogenized in $10 \mathrm{vol} 0.32 \mathrm{M}$ sucrose, $3 \mathrm{mM} \mathrm{MgCl}$ using an Ultra-Turrax homogenizer (Tekmar Co., Cincinnati, OH), and centrifuged at $700 \times g$ for $10 \mathrm{~min}$. The pellet was washed twice with the same buffer containing Triton X-100 (1\%). The nuclear pellet was then resuspended in $0.14 \mathrm{M} \mathrm{NaCl}, 3 \mathrm{mM} \mathrm{MgCl}$, and centrifuged at $700 \times g$ for $10 \mathrm{~min}$. This procedure removes loosely bound proteins and reduces nonspecific binding. The nuclei thus obtained were intact and free of cytoplasmic debris when examined by phase contrast light microscopy. The nuclear receptor was then extracted with $10 \mathrm{ml}$ of TEM buffer [20 mM Tris, $2 \mathrm{mM}$ EDTA, $5 \mathrm{mM} \mathrm{MgCl}_{2}$, $5 \mathrm{mM}$ mercaptoethanol, and $10 \%$ (vol/vol)

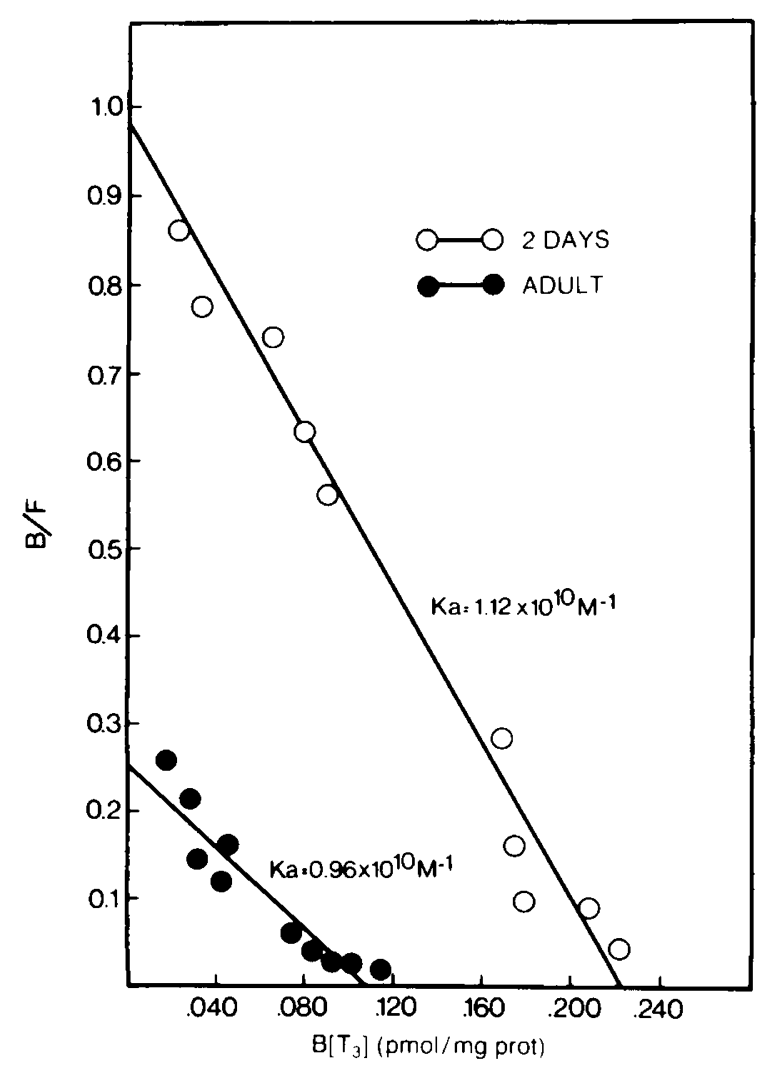

Fig. 1. Scatchard plot of the binding of $\left[{ }^{125} \mathrm{I}\right]-\mathrm{T}_{3}$ to soluble nuclear extracts from lungs of 2-day old and adult rats. The nuclear receptor was extracted from isolated nuclei with $0.4 \mathrm{M} \mathrm{NaCl}$ and incubated at $30^{\circ} \mathrm{C}$ for $40 \mathrm{~min}$. Bound and free hormones were separated by use of Sephadex G25 columns. A significant reduction in binding capacity is observed between neonatal and adult rats $(P<0.001, n=$ four for both groups).
Table 1. Relative binding affinities of thyroid hormone analogs to nuclear extract from developing rat lung ${ }^{1}$

\begin{tabular}{|c|c|c|c|}
\hline \multirow[b]{2}{*}{ Analogs } & \multicolumn{2}{|c|}{ Age (days) } & \multirow[b]{2}{*}{ Adult } \\
\hline & 10 & 20 & \\
\hline Triac & 1.55 & 1.65 & 1.22 \\
\hline L-T ${ }_{3}$ & 1.00 & 1.00 & 1.00 \\
\hline D- $T_{3}$ & 0.68 & & 0.58 \\
\hline $\mathrm{L}-\mathrm{T}_{4}$ & 0.19 & 0.23 & 0.12 \\
\hline $\mathrm{D}-\mathrm{T}_{4}$ & 0.09 & & 0.006 \\
\hline DIMIT & 0.02 & & \\
\hline$L-T_{2}$ & & 0.007 & \\
\hline $\mathrm{rT}_{3}$ & & 0.007 & \\
\hline
\end{tabular}

Results are expressed as the molar ratio of the concentrations of analogs and $\mathrm{T}_{3}$ required to produce $50 \%$ displacement in the binding of $\left[{ }^{125} \mathrm{I}\right] \mathrm{T}_{3}$ $\left(0.2 \times 10^{-10} \mathrm{M}\right)$ to the solubilized nuclear $\mathrm{T}_{3}$ receptor.

glycerol, $\mathrm{pH} 7.85$ ] containing $0.4 \mathrm{M} \mathrm{NaCl}$ as described by Silva $e t$ al. (33). In order to monitor the extraction procedure, 14-, 21-, and 27 -day-old rats as well as adult rats received a tracer dose of $\left[{ }^{125} \mathrm{I}\right]-\mathrm{T}_{3}(<5 \mathrm{ng})$ ip $3 \mathrm{hr}$ before sacrifice and counts were followed in the successive steps of preparation.

\section{BINDING ASSAY}

The binding of $T_{3}$ to the solubilized nuclear receptor $(0.4 \mathrm{ml})$ was performed in TEM buffer in the presence of increasing concentrations of $\left[{ }^{125} \mathrm{I}\right]-\mathrm{T}_{3}$ final concentration ranged from 0.2 to $20 \times 10^{-10} \mathrm{M}$ in $1.0 \mathrm{ml}$. Incubations were carried out at $30^{\circ} \mathrm{C}$ for $40 \mathrm{~min}$ and at $0^{\circ} \mathrm{C}$ for $18 \mathrm{hr}$. This procedure permits the measurement of the maximum binding capacity and calculation of the relative saturation of the nuclear sites, as described by Bernal et al. (3). Bound and free $\left[{ }^{125} \mathrm{I}\right]-\mathrm{T}_{3}$ were separated by gel exclusion chromatography through $2.5-\mathrm{ml}$ columns of Sephadex G-25 fine (33) and the data were analyzed by the method of Scatchard (30).

The relative binding affinities of thyroid hormone analogs were determined by incubating nuclear extracts at $0^{\circ} \mathrm{C}$ for $18 \mathrm{hr}$ with a tracer concentration of $\left[{ }^{125} \mathrm{I}\right]-\mathrm{T}_{3}\left(0.2 \times 10^{-10} \mathrm{M}\right)$ and increasing concentrations of unlabeled TRIAC $\left(0.1\right.$ to $\left.10 \times 10^{-10} \mathrm{M}\right)$, L-T $\left(0.2\right.$ to $\left.20 \times 10^{-10} \mathrm{M}\right), \mathrm{D}-\mathrm{T}_{3}\left(0.4\right.$ to $\left.40 \times 10^{-10} \mathrm{M}\right), \mathrm{L}_{-} \mathrm{T}_{4}(2$ to 200 $\left.\times 10^{-10} \mathrm{M}\right), \mathrm{D}_{4}$, DIMIT, L-T 2 and $\mathrm{rT}_{3}\left(2\right.$ to $\left.200 \times 10^{-9} \mathrm{M}\right)$. Results are expressed as the molar ratio of analogs and $\mathrm{T}_{3}$ required to produce $50 \%$ displacement of $\left[{ }^{125} \mathrm{I}\right]-\mathrm{T}_{3}$ to the solubilized nuclear $\mathrm{T}_{3}$ receptor.

Serum $T_{4}$ concentration was measured by specific radioimmunoassay (6). Protein concentration in the nuclear extracts was determined by the method of Lowry et al. (24) using bovine serum albumin as standard. DNA was measured in the chromatin pellet by the method of Giles and Myers (16). Statistical differences were determined by analysis of variance and by analysis of contrasts when appropriate (10).

\section{RESULTS}

\section{CHARACTERIZATION OF NUCLEAR $T_{3}$ RECEPTOR}

Figure 1 shows representative Scatchard plots of data obtained with solubilized $T_{3}$ receptors in lungs of 2-day-old rats and adult rats. In each case, only one class of binding sites is evident with a mean $\mathrm{Ka}$ of $10^{10} \mathrm{M}^{-1}$. However, nuclear $\mathrm{T}_{3}$ binding capacity in lungs of 2-day-old animals significantly exceeded that of adult rats.

To test the specificity of the nuclear receptor, we compared the relative affinities of different thyroid hormone analogs at various ages (Table 1). TRIAC has been found to be slightly more, and $D-T_{3}$ slightly less effective than $L-T_{3}$ in displacing $\left[{ }^{[25} I\right]-T_{3}$ from the nuclear receptor. ${\mathrm{L}-\mathrm{T}_{4}}_{4}$ has 12 to $23 \%$ the activity of $\mathrm{L}-\mathrm{T}_{3}$ and DIMIT has $2 \%$. Although it is not statistically documented, the 
specificity of the nuclear $T_{3}$ receptor does not appear to change with age.

DETERMINATION OF THE MAXIMUM BINDING CAPACITY AND THE RELATIVE SATURATION OF THE NUCLEAR RECEPTOR

Since circulating thyroid hormone concentrations are higher in adult than in neonatal animals, we used an approach similar to that described by Bernal et al. (3) in order to take account of endogenously bound $T_{3}$ when determining binding capacities. The method is based on the different rates of exchange of bound $T_{3}$ when incubated at different temperatures. The kinetics of dissociation of $\mathrm{T}_{3}$ from the receptor at 0 and $30^{\circ} \mathrm{C}$ are illustrated in Figure 2. As shown by the upper curve of each graph, the loss of receptor is minimal over the time of the experiment. The $t_{1 / 2}$ of dissociation is $21.7 \pm 2.0 \mathrm{~min}$ at $30^{\circ} \mathrm{C}$ and $54 \pm 7 \mathrm{hr}$ at $0^{\circ} \mathrm{C}$ (mean $\pm S . E ., n=3$ ). Similar rates of dissociation of $T_{3}$ bound to the nuclear receptor were observed in neonatal (10-day-old) and adult animals. From these results, we can estimate that the binding capacity measured after $40 \mathrm{~min}$ of incubation at $30^{\circ} \mathrm{C}$ represents unoccupied sites $(\mathrm{U})+72 \%$ of occupied sites $(\mathrm{O})$, while the observed capacity after $18 \mathrm{hr}$ at $0^{\circ} \mathrm{C}$ represents $\mathrm{U}+21 \%$ of $\mathrm{O}$. These equations were solved for $U$ and $O$ and the results, expressed as the maximum binding capacity $(\mathrm{MBC}=\mathrm{U}+\mathrm{O})$ and the relative saturation of the nuclear receptor $(\mathrm{O} / \mathrm{MBC})$, are illustrated in Figure 3.

A significant decrease in the maximum binding capacity of the lung $T_{3}$ receptor occurs between 30 and 40 days of age: 0 to 30 days, $0.208 \pm 0.005$ pmole $T_{3} / \mathrm{mg}$ proteins; 40 days-adulthood, $0.111 \pm 0.007$ pmole $\mathrm{T}_{3} / \mathrm{mg}$ protein (mean \pm S.E., $P<0.01$ ). $\mathrm{T}_{3}$ binding capacity measured at $30^{\circ} \mathrm{C}$ in fetal lungs ( 21 days of gestation $)$ is similar to that of the neonatal rat $(\mathrm{BC}=0.236$ pmole $\mathrm{T}_{3} / \mathrm{mg}$ protein, mean of two experiments). The relative saturation of the nuclear receptor increases from $26 \%$ at 2 days of age to $48 \%$ in the adult animal. The constant of association decreases signifi-
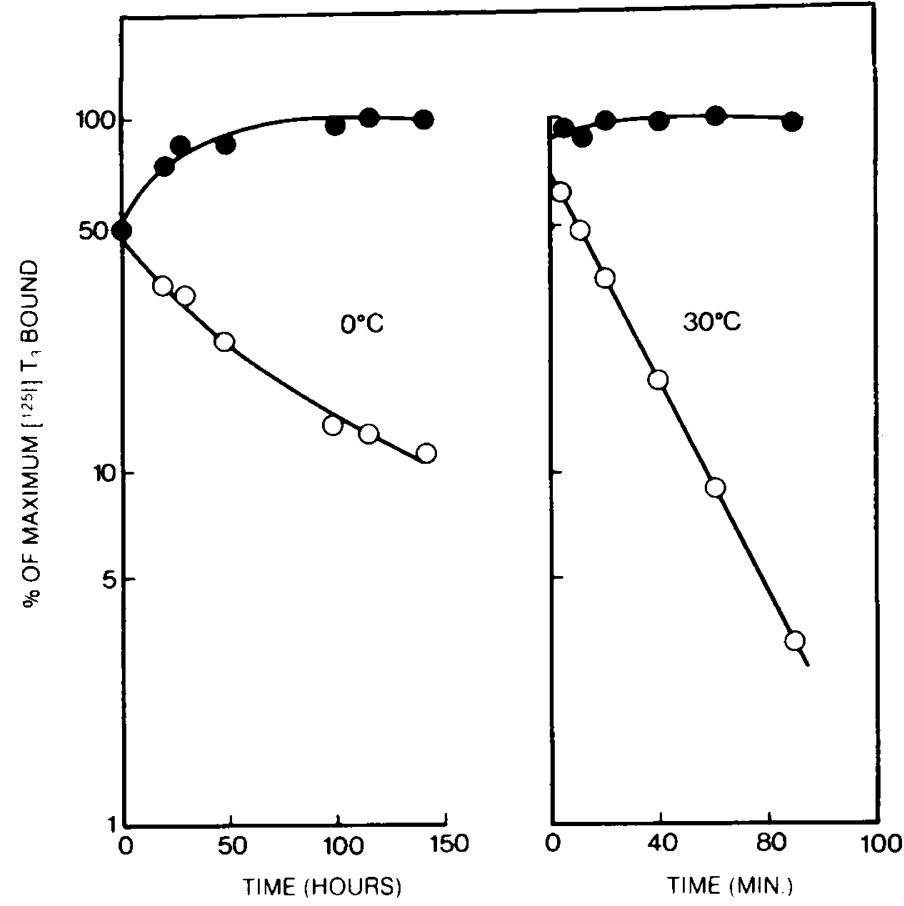

Fig. 2. Rate of dissociation of $T_{3}$ bound to the solubilized nuclear receptor of 20-day-old rat lung. Portions of nuclear extract $(0.4 \mathrm{ml})$ first were incubated with [ $\left.{ }^{125} \mathrm{I}\right]-\mathrm{T}_{3}\left(0.2 \times 10^{-10} \mathrm{M}\right)$ either at $30^{\circ} \mathrm{C}$ for $40 \mathrm{~min}$ or $0^{\circ} \mathrm{C}$ for $18 \mathrm{hr}$. An excess of unlabeled $\mathrm{T}_{3}\left(20 \times 10^{-7} \mathrm{M}\right)$ was then added and, at the indicated time, bound and free hormones were separated. Samples incubated at $30^{\circ} \mathrm{C}$ were chilled on ice for $15 \mathrm{~min}$ before separating bound and free hormones. The $t_{1 / 2}$ of dissociation in this particular experiment are $20 \mathrm{~min}$ at $30^{\circ} \mathrm{C}$ and $50 \mathrm{hr}$ at $0^{\circ} \mathrm{C}$.

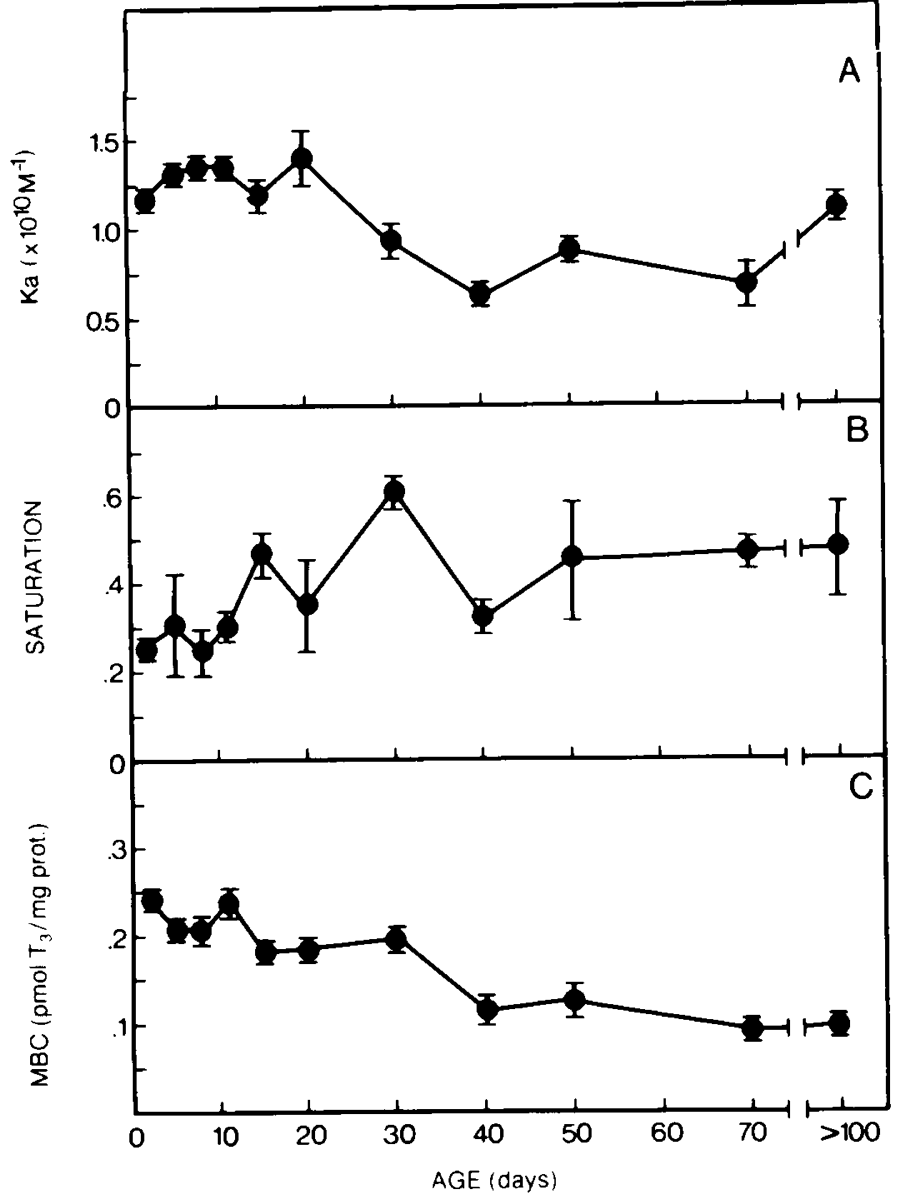

Fig. 3. Characteristics of $T_{3}$ binding to nuclear receptor from rat lung during development. $\mathrm{T}_{3}$ binding capacity was determined at $0^{\circ} \mathrm{C}$ and $30^{\circ} \mathrm{C}$ in nuclear extracts from rat lung at different ages. The maximum binding capacity (MBC) and the relative saturation of the binding sites were calculated from these data by the method of Bernal et al. (13). Values of the constant of association (Ka) are calculated from the mean of 0 and $30^{\circ} \mathrm{C}$ experiments. All results are expressed as the mean \pm S.E. ( $n \geq$ four in all groups). $\mathrm{T}_{3}$ binding capacity measured at $30^{\circ} \mathrm{C}$ in fetal lungs (2I days of gestation) is similar to that of neonatal rat (binding capacity = $0.236 \mathrm{pmole} \mathrm{T}_{3} / \mathrm{mg}$ protein, mean of two experiments).

Table 2. Efficiency of extraction of the $T_{3}$ receptor from lung nuclei at various ages ${ }^{1}$

\begin{tabular}{ccc}
\hline $\begin{array}{c}\text { Age } \\
\text { (Days) }\end{array}$ & $\begin{array}{c}\text { Percentage of }\left[{ }^{125} \mathrm{I}\right]-\mathrm{T}_{3} \\
\text { extracted from nuclei }\end{array}$ \\
\hline 14 & $71.6 \pm 2.1^{2}$ & $(6)^{3}$ \\
21 & $73.4 \pm 2.2$ & $(4)$ \\
27 & $72.2 \pm 3.7$ & $(4)$ \\
Adult & $73.8 \pm 2.0$ & $(14)$ \\
\hline
\end{tabular}

${ }^{1}$ Rats were injected ip with a tracer dose of $\left[{ }^{125} \mathrm{I}\right]-\mathrm{T}_{3}(<5 \mathrm{ng}) 3 \mathrm{hr}$ before sacrifice. Lungs were processed as described in "Materials and Methods" and counts in the $0.4 \mathrm{M} \mathrm{NaCl}$ extract were compared with counts in the nuclei.

${ }^{2}$ Values given are mean \pm S.E.

${ }^{3}$ Numbers of pool of tissue are in parentheses.

cantly $(P<0.01)$ between 20 and 30 days of age from $1.30 \pm 0.05$ $\times 10^{10} \mathrm{M}^{-1}$ ( 2 to 20 days) to $0.91 \pm 0.08 \times 10^{10} \mathrm{M}^{-1}$ (30 daysadulthood).

\section{AGE-RELATED RECOVERY OF THE RECEPTOR}

Experiments were performed in order to rule out the possibility that differences in binding capacity may be due to changes in the 
efficiency of extraction of the receptor from nuclei. Receptors were labeled in vivo with $\left[{ }^{125} \mathrm{I}\right]-\mathrm{T}_{3}$ and counts were followed in the different steps of purification. Table 2 shows the percentage of counts of the purified nuclei fraction (just before extraction) recovered in the $0.4 \mathrm{M} \mathrm{NaCl}$ extract. In each age group, the recovery is greater than $70 \%$ and there is no significant change with age.

Another possibility that could account for the observed reduction in binding capacity is the choice of the index used to express our results, namely the quantity of protein extracted from nuclei. Table 3 shows that the relative difference in binding capacity between young and adult rats is essentially the same whether it is expressed per $\mathrm{g}$ of tissue, per mg of DNA in the chromatin pellet, or per $\mathrm{mg}$ of protein in the nuclear extract (Figure 3 ).

\section{EFFECTS OF HYPO- AND HYPERTHYROIDISM}

We also examined the effects of hypo- and hyperthyroidism on the characteristics of binding of $T_{3}$ to the nuclear receptor (Table 4). Serum $T_{4}$ concentrations were undetectable in hypothyroid rats and were significantly elevated in hyperthyroid rats $(>13 \mu \mathrm{g}$ $\mathrm{T}_{4} / \mathrm{dl}$ ). The constant of association (Ka) is not altered by the treatments except in 11-day-old hypothyroid rats where it is significantly elevated and in adult hypo- and hyperthyroidism where it is significantly decreased $(P<0.01)$.

Hyperthyroidism increases significantly the nuclear $T_{3}$ binding capacity in lungs of adult animals $(P<0.01)$. DNA was not measured in these experiments but the relative difference is similar when expressed per $\mathrm{g}$ of wet tissue. Neither hyperthyroidism nor hypothyroidism significantly affect the binding capacity in other groups.

\section{DISCUSSION}

The data presented herein confirm and extend previous observations on the presence of nuclear $T_{3}$ receptor in the lung $(23,26)$.

Table 3. Binding capacity $(B C)$ of nuclear $T_{3}$ receptor $^{1}$

\begin{tabular}{ccccc}
\hline $\begin{array}{c}\text { Age } \\
\text { (days) }\end{array}$ & $\begin{array}{c}\text { BC } \\
\text { (pmole } \mathrm{T}_{3} / \text { g wet tis- } \\
\text { sue) }\end{array}$ & $\begin{array}{c}\mathrm{BC} \\
\text { (pmole } \mathrm{T}_{3} / \mathrm{mg} \text { DNA) }\end{array}$ \\
\hline 5 & $1.60 \pm 0.06^{2}$ & $(4)^{3}$ & & \\
9 & $1.59 \pm 0.14$ & $(7)$ & & \\
11 & $1.56 \pm 0.10$ & $(6)$ & & \\
21 & $1.67 \pm 0.11$ & $(4)$ & $0.499 \pm 0.029$ & $(4)$ \\
27 & $1.76 \pm 0.04$ & $(4)$ & $0.622 \pm 0.043$ & $(4)$ \\
Adult & $0.854 \pm 0.035$ & $(16)$ & $0.296 \pm 0.025$ & $(12)$ \\
\hline
\end{tabular}

\footnotetext{
' Binding capacity was determined by analysis of Scatchard after an incubation period of $40 \mathrm{~min}$ at $30^{\circ} \mathrm{C}$. Data are expressed as pmoles $\mathrm{T}_{3}$ bound per $g$ of tissue and, when available, per mg of DNA in the chromatin pellet after extraction of the receptor with $0.4 \mathrm{M} \mathrm{NaCl}$ buffer.

${ }^{2}$ Values given are mean \pm S.E.

${ }^{3}$ Numbers of pool of tissue are in parentheses.
}

In all ages studied, we found a single class of binding sites with a mean $\mathrm{Ka}$ of $1.16 \pm 0.05 \times 10^{10} \mathrm{M}^{-1}$, which is slightly higher than that reported earlier. The decrease of $\mathrm{Ka}$ that we observe with age is concomitant with the increase of the saturation level and so, might be due to the presence of endogenous hormone since our binding assays are not performed at complete equilibrium.

The specificity of the nuclear receptor, as judged by the relative affinities of thyroid hormone analogs, is in general agreement with data previously reported for lung and other organs $(22,23,26)$. The relative affinity of DIMIT for the nuclear receptor is of interest since, in contrast with $T_{3}$ and $T_{4}(11,12)$, it crosses the placental barrier (7). Ballard et al. (1) recently reported that administration of this compound to pregnant rabbits accelerates the fetal lung maturation at doses compatible with the relative affinity we measured.

Lindenberg et al. (23) reported a $50 \%$ decrease in $\mathrm{T}_{3}$ binding capacity of adult rabbit lung when compared with the fetus (23). We measured a similar decrease and in addition, determined, that it occurs mainly between 30 and 40 days of age in the rat lung. Our experiments showed that this reduction is not due to differential recovery of nuclei or efficiency of extraction at various ages, and attest the validity of expressing the results per mg of protein, at least in normal animals. With respect to binding capacity, lungs behave like the brain where receptor level is higher in younger animals $(32,35)$. In the brain, this time of high receptor density is correlated with the time of critical dependence of the brain on thyroid hormones for proper maturation. By analogy, the lung receptor level during the first month of life suggests a special role for thyroid hormones at this time. However, one must be aware that thyroid hormone binding is not necessarily equivalent to thyroid hormone action and additional experiments appear necessary to clearly establish this relationship during lung maturation. It is also possible that the receptor is not uniformly distributed in every cell type and that a decrease in the proportion of $T_{3}$ receptorcontaining cells in the lung would result in an apparent decrease of $T_{3}$ binding capacity.

The changes with age in the relative saturation of the binding sites are closely related to the developmental pattern of serum $T_{3}$ concentration (13) suggesting a direct equilibrium between nuclear and serum $T_{3}$. This is further supported by its striking similarity with the saturation level we measured in liver receptors $(8)$ where the local formation of $T_{3}$ contributes relatively little to the saturation level (34). It is also interesting to note that the decrease in maximum binding capacity occurs at a time when serum $T_{3}$ concentration and relative saturation of the binding sites reach their maximum, suggesting, in addition, that thyroid hormones might control the number of their nuclear receptors. Such a mechanism has been demonstrated in $\mathrm{GH}_{1}$ cells (29).

In order to check this possibility, we measured the effects of hypo- and hyperthyroidism on nuclear receptors from developing and adult animals. Since normal lactation requires the presence of thyroid hormones (9), particular care was taken to keep the mother euthyroid when inducing neonatal hypothyroidism. This could be important since fasting has been reported to decrease receptor

Table 4. Effect of hypo- and hyperthyroidism on the equilibrium association constant (Ka) and the nuclear $T_{3}$ binding capacity in neonatal and adult rat ${ }^{1}$

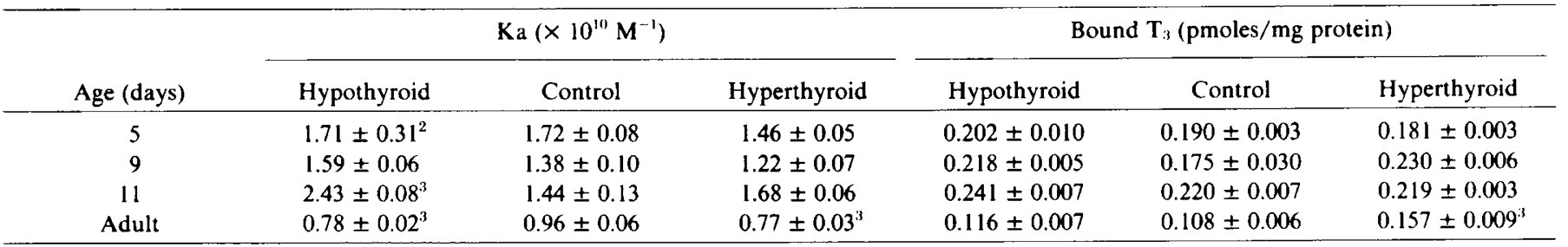

${ }^{1}$ Hypothyroidism was induced by PTU administration. Hyperthyroidism was induced by daily injection of $40 \mu \mathrm{g} \mathrm{T} / 100 \mathrm{~g}$ body wt from birth to the days indicated in neonatal rats, and for a period of 6 days in the adult animal. Nuclear extracts were incubated with increasing concentrations of [ $\left.{ }^{125} \mathrm{I}\right]$ $-\mathrm{T}_{3}$ at $30^{\circ} \mathrm{C}$ for $40 \mathrm{~min}$. Determinations were performed simultaneously in control and treated rats of the same age.

${ }^{2}$ Values given are mean \pm S.E. ( $n=4$ for each group except adult hyperthyroid rats $\left.n=8\right)$.

${ }^{3}$ Significantly different from controls, $P<0.01$. 
capacity in the liver (31). Our results indicate that thyroid status has no significant effect on the nuclear $T_{3}$ binding capacity of developing rat lung up to 11 days of age. However, hyperthyroidism substantially increased the binding capacity in lungs of the adult animal $\left(0.157 \pm 0.009\right.$ versus $0.108 \pm 0.006$ pmole $T_{3} / \mathrm{mg}$ protein) without a corresponding reduction in hypothyroidism $\left(0.116 \pm 0.007\right.$ pmole $T_{3} / \mathrm{mg}$ protein). This is in contrast with studies in other tissues where the binding capacity is unchanged or decreased by thyroid hormones $(3,29)$. However, Hamada et al. (18) recently reported that $\mathrm{T}_{3}$ could induce an increase in the nuclear $T_{3}$ binding capacity and suggested that this event is involved in the subsequent increase of mitochondrial $\alpha$-glycerophosphate dehydrogenase activity (18). The lack of effect we observed during the neonatal period may be due to the fact that binding capacity is already high at this time.

Until now, most studies on the effects of thyroid hormones on the lung have focused on the prenatal period. Nuclear $T_{3}$ receptors are present in the fetus and could thus account for the observed effects on surfactant metabolism in the rat. However, the concentrations of thyroid hormones are very low in normal fetal rats (11, 12). If they influence the normal development of the fetal lung, they must do so at low levels of saturation of nuclear receptors. Nevertheless, sensitivity of the lung to thyroid hormones could be increased by interactions with glucocorticoids as pointed out by Hitchcock (20). Our study indicated that maximum binding capacity remains at the fetal level up to 30 days of age. In the meantime, the relative saturation of the binding sites increases to $60 \%$ in 30-day-old rats. These findings suggest that thyroid hormones play a yet unspecified important role in lung physiology during the first month of life in the rat. In this regard it would be interesting to examine the effects of thyroid hormones on alveolarization which, in the rat, occurs in the first 3 postnatal wk (4).

\section{REFERENCES AND NOTES}

I. Ballard, P. L., Benson, B. J, Brehier, A., Carter, J. P., Kirz, B. M., and Jorgensen, E. C.: Transplacental stimulation of lung development in the fetal rabbit by 3,5-dimethyl-3'-isopropyl-L-thyroxine. J. Clin. Invest., 65: 1407 (1980).

2. Baxter, J. D., Eberhardt, N. L., Apriletti, J. W., Johnson, L. K., Ivarie, R. D., Schacter, B. S., Morris, J. A., Seeburg, P. H., Goodman, H. M., Latham, K. R., Polansky, J. R., and Martial, J. A.: Thyroid hormone receptors and response. Recent Prog. Horm. Res., 35: 97 (1979).

3. Bernal, J., Coleoni, A. H., and DeGroot, L. J.: Thyroid hormone receptors from liver nuclei: characteristics of receptor from normal, thyroidectomized, and triiodothyronine-treated rats; measurement of occupied and unoccupied receptors and chromatin binding of receptors. Endocrinology, 103: 403 (1978).

4. Burri, P. H.: The postnatal growth of the rat lung. III. Morphology. Anat. Rec., 180: 77 (1974).

5. Burri, P. H., Dbaly, J., and Weibel, E. R.: The postnatal growth of the rat lung. I. Morphometry. Anat. Rec., 178: 711 (1974).

6. Chopra, I. J.: A radioimmunoassay for measurement of thyroxine in unextracted serum. J. Clin. Endocrinol. Metab., 34: 938 (1972).

7. Comite, F., Burrow, G. N., and Jorgensen, E. C.: Thyroid hormone analogs and fetal goiter. Endocrinology, 102: 1670 (1978).

8. Coulombe, P., Ruel, J., Dussault, J. H.: Analysis of nuclear 3,5,3'-triiodothyronine-binding capacity and tissue response in the liver of the neonatal rat. Endocrinology, 105: 952 (1979).

9. Cowie, A. T.: Anterior pituitary function in lactation. In: G. W. Harris, B. T. Donovan: The Pituitary Gland. Vol. II. p. 412 (University of California Press, Los Angeles, CA 1966).

10. Dixon, W. J., and Massey, F. J.: Introduction to Statistical Analysis, 3rd ed., (McGraw-Hill, New York, 1969)

11. Dubois, J. D., Cloutier, A., Walker, P., and Dussault, J. H.: Absence of placental transfer of $\mathrm{L}$-triiodothyronine $\left(\mathrm{T}_{3}\right)$ in the rat. Pediatr. Res., 11: 116 (1977).

12. Dussault, J. H., and Coulombe, P.: Minimal placental transfer of thyroxine $\left(T_{4}\right)$ in the rat. Pediatr. Res., 14: 228 (1980).

13. Dussault, J. H., and Labrie. F.: Development of the hypothalamo-pituitary- thyroid axis in the neonatal rat. Endocrinology, 97: 1321 (1975).

14. Erenberg, A., Rhodes, M. L., Weinstein, M. M., and Kennedy, R. L.: The effect of fetal thyroidectomy on ovine fetal lung maturation. Pediat. Res., 13: 230 (1979).

15. Farrell, P. M. and Avery, M. E.: Hyaline membrane disease. Am. Rev. Respir. Dis., 111: 657 (1975).

16. Giles, K. W., and A. Myers: An improved diphenylamine method for the estimation of deoxyribonucleic acid. Nature (Lond.). 206: 93 (1965).

17. Greenberg, A. H., Najjar, S., and Blizzard, R. M.: Effects of thyroid hormone on growth, differentiation, and development. In: M. A. Greer, D. H. Solomon: Handbook of Physiology, Sect. 7, Vol. III. p. 377 (American Physiological Society, Washington D.C., 1974).

18. Hamada, S., Nakamura, H., Nanno, M., and Imura, H.: Triiodothyronineinduced increase in rat liver nuclear thyroid-hormone receptors associated with increased mitochondrial $\alpha$-glycerophosphate dehydrogenase activity. Biochem. J., 182: 371 (1979).

19. Hemberger, J. A., and Schaker, L. S.: Effect of thyroxine on permeability of the neonatal rat lung to drugs. Biol. Neonate, 34: 299 (1978).

20. Hitchcock, K. R.: Hormones and the lung. I. Thyroid hormones and glucocorticoids in lung development. Anat. Rec., 194: 15 (1979).

21. Kauffman, S. L., Burri, P. H., and Weibel, E. R.: The postnatal growth of the rat lung. II. Autoradiography. Anat. Rec., 180: 63 (1974).

22. Koerner, D., Surks, M. I., Oppenheimer, J. H.: In vitro demonstration of specific triiodothyronine binding sites in rat liver nuclei. J. Clin. Endocrinol. Metab.. 38: 706 (1974)

23. Lindenberg, J. A., Brehier, A., and Ballard, P. L.: Triiodothyronine nuclear binding in fetal and adult rabbit lung and cultured lung cells. Endocrinology, 103: 1725 (1978)

24. Lowry, O. H., Rosebrough, N. Y., Farr, A. L., and Randall, R. J.: Protein measurement with the Folin phenol reagent. J. Biol. Chem., 193: 265 (1951).

25. Mashiach, S., Barkai, G., Sack, J., Stern, E., Goldman, B., Brish, M., and Serr, D. M.: Enhancement of fetal lung maturity by intra-amninotic administration of thyroid hormone. Am. J. Obstet. Gynecol., 130: 289 (1978).

26. Morishge, W. K. and Guernsey, D. L.: Triiodothyronine receptors in rat lung. Endocrinology, 102: 1628 (1978).

27. Oppenheimer, J. H.: Thyroid hormone action at the cellular level. Science, 203: 971 (1979).

28. Reddings, R. A., Douglas, W. H. L., and Stein, M.: Thyroid hormone influence upon lung surfactant metabolism. Science, 175: 994 (1972).

29. Samuels, H. H., Stanley, F., and Shapiro, L. E.: Modulation of thyroid hormone nuclear receptor levels by 3,5,3'-triiodo-L-thyronine in $\mathrm{GH}_{1}$ cells: evidence for two functional components of nuclear-bound receptor and relationship to the induction of growth hormone synthesis. J. Biol. Chem., 252: 6052 (1977).

30. Scatchard, G.: The attraction of proteins to small molecules and ions. Ann. N.Y. Acad. Sci., 51: 660 (1949).

31. Schussler, G. C., and Orlando, J.: Fasting decreases triiodothyronine receptor capacity. Science, 199: $686(1978)$

32. Schwartz, H. L., and Oppenheimer, J. H.: Ontogenesis of 3,5,3'-triiodothyronine receptors in neonatal rat brain: dissociation between receptor concentration and stimulation of oxygen consumption by 3,5,3'-triiodothyronine. Endocrinology, 103: 943 (1978).

33. Silva, E. J., Astier, H., Thakare, U., Schwartz, H. L., and Oppenheimer, J. H.: Partial purification of the $T_{3}$ receptor from rat liver nuclei: differences in chromatographic mobility of occupied and unoccupied sites. J. Biol. Chem., 252: 6799 (1977)

34. Silva, J. E., Dick, T. E., and Larsen, P. R.: The contribution of local tissue thyroxine monodeiodination to the nuclear 3,5,3'-triiodothyronine in pituitary, liver, and kidney of euthyroid rats. Endocrinology, 103: 1196 (1978).

35. Valcana, T. and Timiras, P. S.: Nuclear triiodothyronine receptors in the developing rat brain. Mol. Cell. Endocrinol., 11: 31 (1978).

36. Wu, B., Kikkawa, Y., Orzalizi, M. M., Motoyama, E. K., Kaibara, M., Zigas, C J., and Cook, C. B.: The effect of thyroxine on the maturation of fetal rabbit lungs. Biol. Neonate, 22: 161 (1973).

37. The authors wish to express their appreciation to Dr. Peter Walker for his helpful criticism in reviewing this manuscript, Nicole Beaudoin, Louise C. Dussault, and Lise Garceau for their expert technical assistance and Michele Boissonneault for the preparation of this manuscript.

38. Requests for reprints should be addressed to: Dr. Pierre Coulombe, Laboratoires de Recherches en Endocrinologie et Métabolisme, Le Centre Ho\&pitalier de l'Université Laval, 2705 Boul. Laurier, Ste-Foy, Québec GIV $4 G 2$.

39. This research was supported by MRC Grant MA-6204.

40. Dr. P. Coulombe is a scholar from MRC.

41. Received for publication November $12,1980$.

42. Accepted for publication February 10, 1981 